\title{
心臓弁膜と大動脈・冠動脈における硬化性病変の関連性と相違点 剖検例による病理学的比較検討
}

\author{
富樫真由子 ${ }^{1}$ 田村 $\quad$ 浩一 ${ }^{2}$ 萬里小路直樹 ${ }^{1}$ 福田 悠 ${ }^{3} \quad$ 杉崎 祐一 $^{2}$ \\ ${ }^{1}$ 昭和女子大学大学院生活機構研究科 \\ 2 日本医科大学付属病院病理部 \\ ${ }^{3}$ 日本医科大学病理学第 1 教室
}

Comparative Study on the Sclerotic Changes of Cardiac V alve and Blood V essel

\author{
Mayuko T ogashi ${ }^{1}$, Koichi T amura ${ }^{2}$, Naoki Madenokouji ${ }^{1}$, Y uh Fukuda ${ }^{3}$ and $Y$ uichi Sugisaki ${ }^{2}$ \\ ${ }^{1}$ Department of Human Nutrition and Environmental Design, Show a Women's Graduate School of Human Ecology, T okyo, Japan \\ ²Division of Surgical Pathology, Nippon Medical School Hospital, T oky o, Japan \\ ${ }^{3}$ Department of Pathology I, Nippon Medical School, T oky o, Japan
}

\begin{abstract}
A bstr act
Background: Recently, there is an increase in number of surgical treatments for the aortic stenosis caused by valvular sclerosis with aging. Whether valvular sclerosis are related to aortic atherosclerosis, the prevention therapy of arteriosclerosis may benefit the clinical treatment of the valvular dy sfunction due to aging.

Materials and Methods: Gross, histological and immunohistochemical studies were made on 159 autopsy cases (97 men, 62 women, mean age 65.1 years old). T he degree of sclerotic change in aortic valve ( $\mathrm{AV}$ ), mitral valve ( $\mathrm{MV}$ ), aorta ( $\mathrm{O} 0$ ) and coronary artery ( $\mathrm{CA}$ ) was classified by gross examination to none, mild, moderate, and severe, scored as 0 to 3 , respectively. The data were statistically analyzed by the correlation test. T o observe the expression of bone related proteins in valve calcification, indirect immunostaining procedures were applied with antibodies to osteocalcin, osteopontin and osteonectin.

Results: Grossly, there was a significant correlation in sclerotic change between $A \circ$ and $A V, A o$ and $M V, A V$ and $M V, C A$ and $A V$, and $C A$ and $M V$, respectively $(p<0.01)$. A Iso, the degree of sclerotic change in each tissue was correlated with patients' age. However, the grade of sclerotic change of each tissue was variant in each case. On gross observation, all valvular sclerosis showed yellowish thickening and/or calcification. Microscopically, hy alinous change of the fibrosa was observed in the yellowish lesion of the valves. A ccumulations of foamy macrophages were found focally at the surface area of the fibrosa, but no atheromatous change was observed in the valves. Calcified deposits, if present, were found in the fibrous valvular ring or fibrosa with hyalinous degeneration. In MV, calcification was usually localized in the fibrous ring. However, in A V, valvular calcification extended diffusely in the fibrosa and caused stenosis in some cases. These lesions were similar to calcified area in the intima with fibrous thickening of $\mathrm{A} o$ and/or CA, but were different from atheromatous lesion of these tissues. Immuno-
\end{abstract}

Correspondence to Koichi T amura, MD, DMSc, Division of Surgical Pathology, Nippon Medical School Hospital, 1-1-5 Sendagi, Bunky o-ku, T oky o, 113-8603, Japan

E-mail:tamura@nms.ac.jp

Journal Website (http://www.nms.ac.jp/jnms/) 
histochemically, calcified areas of valves showed stronger reaction for osteocalcin than that of vessels.

Conclusion: A mong scler otic change of cardiac valves and arteriosclerosis, statistical correlations were found, but pathological features were different. Main causes of these differences are thought to be 1) not only the shear stress, but also intramural pressure and mechanical stress with opening and closing may interfere the sclerotic change of cardiac valves, and 2) mechanism of valvular sclerosis may be different from arteriosclerosis because medial smooth muscle cells are absent in the valves. (J Nippon Med Sch 2003; 70: 496-508)

Key words: arteriosclerosis, sclerotic change of cardiac valve, calcification, bone related protein, pathology

\section{緒 言}

近年，心藏弁膜の加齢性硬化による狭窄症の手術例 が増加しているが1 , これには手術適応が高齢者まで 拡大したことに加えて, 日本人の間で動脈硬化症や心 藏弁膜硬化症の症例が増加したことも関連していると 考えられる . 今後も人口の高齢化に伴い , ますます加 齢に伴う心臓弁膜疾患が増加することが予想され，動 脈硬化症だけでなく，心臓弁膜硬化についても何らか の対策が必要と思われる. 現在, 動脈硬化症に対する 樣々な予防法や治療法があるが-4, 心藏弁膜の硬化と 大動脈硬化の機序に関連性があるならば，動脈硬化に 対する予防的治療が弁の硬化症への予防にもつながる と考えられる．光こで今回剖検例を用いて，心藏弁膜 硬化と動脈硬化の関連性および機序の違いについて検 討した。

\section{対象と方法}

1997〜1999 年の日本医科大学付属病院における剖 検症例のうち, リウマチ性弁膜症, 感染性心内膜炎, 胎児例を除いた 159例（男性 97 例，女性 62 例，年齢 9 歳〜91歳, 平均年齢 65.1 歳) を対象とした。

\section{1. 肉眼所見による硬化度判定と統計解析}

対象例の大動脈 ( $\mathrm{A} O$ o), 冠動脈 ( CA ), 大動脈弁 $(A \vee)$, 僧帽弁 $(M V)$ を肉眼的に観察し, A o , A V , $M V$ については硬化の程度 (硬化度) を, なし ( - ) , 軽度 $(+)$, 中等度 $(++)$, 高度 $(+++)$ の4段階 で評価し，0から 3 点に数值化した．ただし領域によ って所見に差があるために $(+\sim++)$ など評価した 症例も多く，数值化は各段階の中間に当たるものを 0.5 単位で加えた 7 段階で行った (T able 1a).CA につ
いては, 左右冠動脈の入口部から 1.5 2 cm の領域を 主体に検索し，最も高度な狭窄部位での狭窄率を $5 \%$ 単位で評価した ( T able 1b).

これらの肉眼的評価をもとに Ao，CA，A V , MV 光れ光れの硬化度についての相互の関連性, および年 齢と各組識の硬化度との関連性について統計学的に検 討した．統計解析では相関分析を用いて，A o-A V ,A o$M V ， C A-A V ， C A-M V ， A V-M V$ の各組織間および 年齢と各組織の硬化度間における相関係数および回帰 直線を求めた .

\section{2. 組織学的検討}

A o ，CA，A V，MV の光れ光れについて，硬化の ないものから高度のものまで典型的な肉眼所見を呈し た 42例（男性 24例，女性 18例，年齢 23～91歳, 平 均 65.7 歳) を選び, 所見のある各部位を切り出した . これらのパラフィン切片を作製し, Hematoxylin and Eosin (H-E) 染色およびElastica-Masson Goldner $(E M G)$ 染色を施して病理組織学的に検討した .

\section{3. 免疫組織化学的検討}

光顕標本を作製した 42 例中，各硬化段階の組織像 として典型的な 13例（男性 8例，女性 5例，50９1 歳, 平均 68.2 歳) を選び, osteonectin (ON), osteopontin (OPN), osteocalcin (OC), $\alpha$ 平滑筋アクチ ン $(\alpha-S M A)$, ビメンチン, macrophage (KP-1) (T able 2)について, 酵素抗体法 [A BC kit ,DA KO ， Glostrup, Denmark] を用いて免疫組織化学的に検 討した。

\section{結 果}

1. 肉眼所見

(1) 各組識の硬化所見 
T able 1a Classification of the degree of scler otic changes. T he degree of scler otic change in A o, A V , MV were classified accoding to the findings of gross ex amination ${ }^{5-7}$

\begin{tabular}{l|ccl}
\hline \multicolumn{1}{c|}{ Sclerosis } & A orta & Valve & Score \\
\hline none & normal & normal & $0(-)$ \\
none-mild & fatty streak $^{*}$ & focal y ellowish change & $0.5( \pm)$ \\
mild & & 1 & $(+)$ \\
mild-moderate & fibrous plaque & diffuse y ellowish change with & $1.5(+\sim++)$ \\
moderate & & thickening & $2(++)$ \\
moderate-marked & complicated lesion & calcification & $2.5(++\sim++)$ \\
marked & & & $3(++)$ \\
\hline
\end{tabular}

T able $1 \mathrm{~b}$ The rates of narrowing of the coronary artery (CA)

\begin{tabular}{c|c}
\hline Sclerosis & Score \\
\hline normal & $0 \%$ \\
narrowing & goes up by $5 \%$ \\
\hline
\end{tabular}

From gross examination, the rate of narrowing of CA was classified to normal or narrowing, then gave the score that goes up by $5 \%$. The examination area w as $1.5 \sim 2 \mathrm{~cm}$ distal side from the ostium of either left or right CA. A score was determined as the most narrowed vessel among LA D, LCX and RCA.

大動脈では，硬化の軽度な例では線状または斑状の 黄色調のわずかな膨隆 (fatty streak ${ }^{5}$ ) か椎骨動脈分 岐部などを中心に分布し (Fig.1a)，中等度の例では 硬く内腔に膨隆する fibrous plaque ${ }^{6}$ (Fig.1b) が主 体であった.高度とした病変 (complicated lesion ${ }^{7}$ ) では粥腫の形成や乥の崩れ，灰白調を呈する硬い石灰 沈着などを認めた (Fig.1c) .

冠動脈では, 狭窄が $20 \%$ 以下の軽度例は 108 例 $(77 \%), 50 \%$ 以上の高度例は 25 例（18\%）であっ た . 検討例の中に粥腫破綻や新鮮血栓の見られたもの はなかった 。

各弁膜は透過性のある薄い膜であるが, 軽度 (Fig. 2a) から中等度 (Fig. 2b，c) の硬化では弁輪側中心 に斑状の黄色調肥厚がみられた . A V の高度硬化例で は弁膜全体が肥厚して石灰沈着により可動性も低下し ていた (Fig. 2d) が，MVでは弁輪に硬い石灰沈着 が認められるものの (Fig. 2e), 弁膜全体に石灰沈着 が及、例はなかった 。

（2）肉眼的評価に基づく心蔵弁膜硬化と大動脈・冠 動脈硬化の関連性

肉眼的硬化度の数值化から大動脈弁 - 僧帽弁の硬化 と大動脈・冠動脈硬化の各々について関連性を求める と, A o-A V 間 (Fig. 3a)，A o-MV 間 (Fig. 3b) , A V-
$M V$ 間 (Fig. 3c) では強い相関が認められ, CA-AV 間 (Fig. 3d)，CA-MV 間 (Fig.3e) では弱い相関が 認められた .

しかし，統計学的には相関か認められたものの，各 組織間の硬化度に 1.5 以上の開きがある症例がA oA V 間で51例 (32\%)，A o-MV 間で42例 (26\%), A V-MV 間で3例 (2\%) みられ，個 々の症例でみる と各組識の硬化度は必ずしも一致していなかった .

年齢との関連では各組識ともに, 加齢と硬化度に正 の相関か認められた . 相関は, A o(Fig. 4a) , A V (Fig. 4b), MV (Fig. 4c) で強く, CA (Fig. 4d) では弱 い傾向にあった .

\section{2 . 組織所見}

(1) 大動脈・冠動脈の硬化像

硬化のめだたないA o, CA の壁は, 内膜, 中膜, 外膜の 3 層構造が明瞭であった . 弾性動脈である A 。 の内膜は薄く，中膜には輪状にとりまく弾性板と光の 間にある膠原性結合組織および平滑筋細胞が認められ た、筋性動脈であるCA は, 小巟例でも A oに比較し て内膜は厚く, 中膜には豊富な平滑筋か認められた .

A oでは, fatty streak 主体の軽度な硬化部で，びま ん性の線維性内膜肥厚部の中に, 泡沫化した macrophage または平滑筋細胞の集簇がみられた . 肉眼的に fibrous plaque とした病変の中には, 中心がコレステ リン結晶，細胞崩壊物質の蓄積で無構造となり，糕腫 樣を呈しているものが含まれていた (Fig. 5a) . 高度 な硬化部では，きわめて脂質に富む粥腫を主体とした もの (Fig. 5b) と, この粥腫に石灰沈着をきたして いるもの (Fig. 5c)，または線維性肥厚が主体となり 同部に石灰沈着をきたしているもの (Fig. 5d) が観 察された .

CA では，線維性内膜肥厚が主体のもの(Fig.6a)， 粥腫形成 (Fig. 6b) および同部への石灰沈着 (Fig. 6c) によって内腔狭窄をきたしているもの，血管全周にわ 
T able 2 A ntibodies used for immunohistochemistry

\begin{tabular}{l|ccc}
\hline \multicolumn{1}{c|}{ antibodies } & clone & working dilution & sources \\
\hline KP-1 (CD 68) & KP-1 & $1 \times 600$ & DA KO, Glostrup, Denmark \\
$\alpha$ smooth muscle actin & $1 A 4$ & $1 \times 500$ & DA KO, Glostrup, Denmark \\
Vimentin & V 9 & $1 \times 100$ & DA KO, Glostrup, Denmark \\
Osteonectin & polyclonal & $1 \times 500$ & CHEMICON, T emecula, CA, USA \\
Osteopontin & polyclonal & $1 \times 200$ & CHEMICON, T emecula, CA, USA \\
Osteocalcin & polyclonal & $1 \times 500$ & CHEMICON, T emecula, CA, USA \\
\hline
\end{tabular}

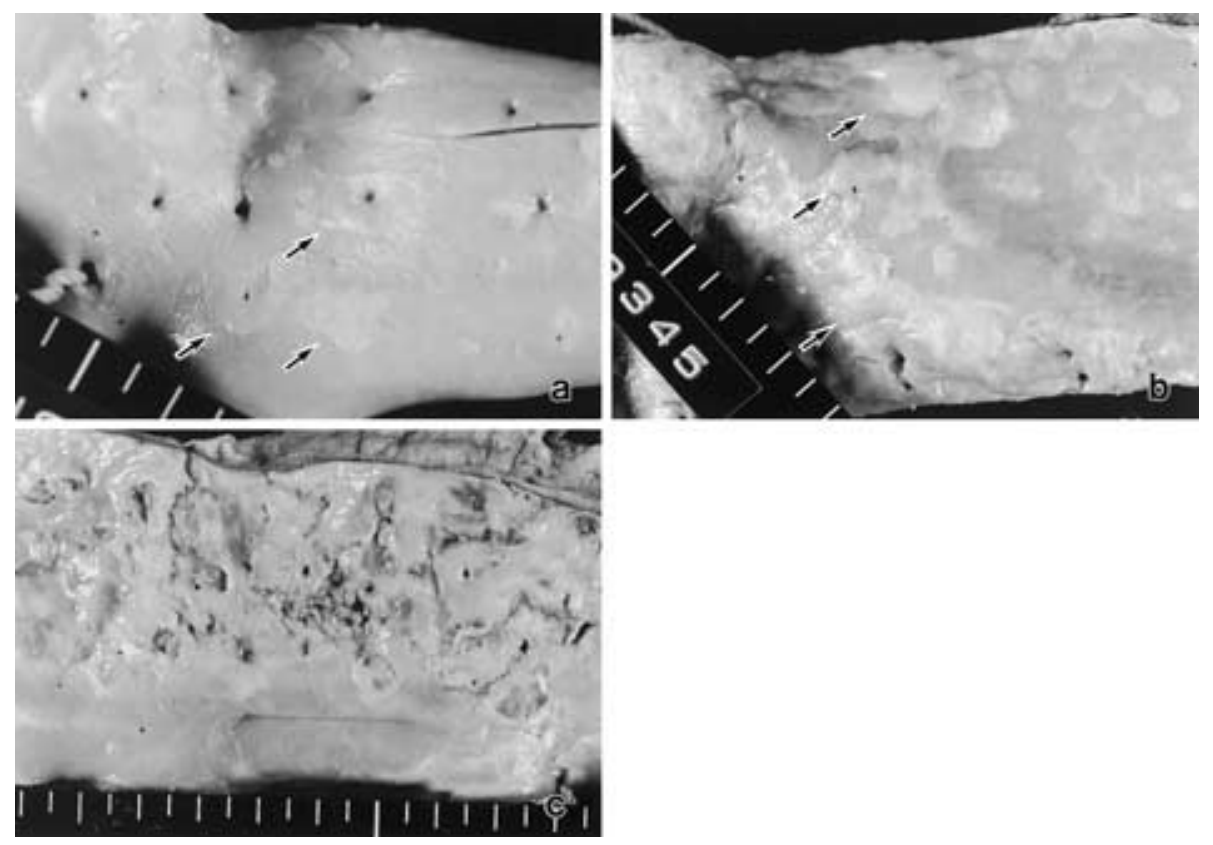

Fig. 1 Gross pathologic findings of scler otic changes in aorta.

a. Mild sclerotic change.

Scattered fatty streaks (arrows) are found in the descending thoracic aorta.

b. Moder ate scler osis.

Fibrous plaques (arrows) are scattered in the descending thor acic aorta.

c. Marked sclerosis.

Multiple ulcers with atheromatous lesions and calcifications are present in the descending thoracic aorta.

たる石灰沈着により拡張を示しているもの (Fig. 6d) が認められた .

(2) 弁膜の硬化像

心臓弁膜の基本構造はいずれも同一で, 閉鎖時に圧 を受ける側 ( A V の大動脈面，MV の左室面) の厚い 膠原線維から成る層(fibrosa), 血液が流入する側 ( $\mathrm{AV}$ の左室面，MV の左房面)の弾性線維の豊富な層(elastic lay er ), 兴の 2 層の間の粗な結合織間に紡錘形細胞 (筋線維芽細胞) が分布する層 (spongiosa) の, 3 層が主体であった . 弁膜の両表面は血管および心腔か ら連続する内皮細胞が覆っており，弁輪基部では fibrosaに連続する厚い線維輪がみられた .

組織学的検索で, 弁膜の fibrosa 側で局所的に ma- crophage の出現が認められる例があったが , 粥腫の 形成に至るものはなかった . macrophage の集簇は, 弁の開閉の支点となる弁輪部付近に多くみられたが， 一部の症例で弁膜中央部にも認められた . いずれも内 皮下が主体であり，fibrosa 内への macrophage の浸 潤はわずかにみられるのみであった (Fig. 7a) .

肉眼的に黄色調を呈する領域は, fibrosaの膠原線 維が無構造となり硝子樣変性を示していた (Fig. $7 \mathrm{~b})$ ．－部の症例で線維間にコレステリン結晶がみら れることがあったが, 分布は散在性であり, 動脈にみ られる粥種の所見とは異なっていた (Fig. 7c).

石灰沈着は, 弁輪の線維輪 (Fig. 7d) または弁膜 fibrosaの硝子樣変性部に生じていた．AVでは, 弁輪 

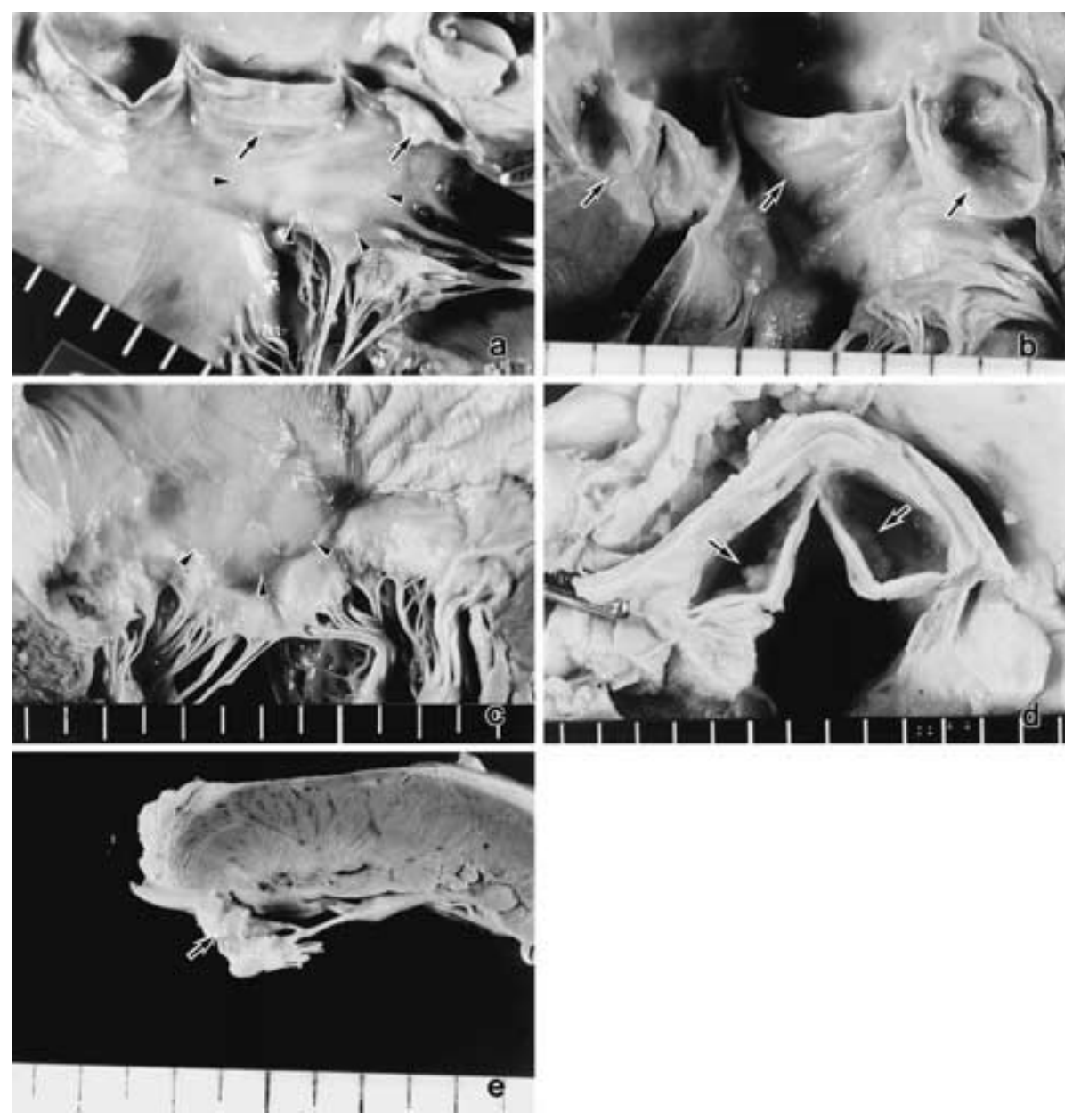

Fig. 2 Gross pathological findings of sclerotic changes in aortic and mitral valves. a. Mild sclerotic change of aortic and mitral valves.

Focal yellowish thickening is localized at the cuspal ring area (arrows) of the aortic valve and ring side of the anterior mitral leaflet (arrowheads).

b. Moder ate to marked sclerosis of an aortic valve.

Diffuse yellowish thickening with minimal calcific deposits are found in the cusps (arrows).

c. Moderate sclerosis of a mitral valve.

Diffuse yellowish thickening are found in both leaflets (arrowheads), but there are no calcific deposit.

d. Marked sclerosis of an aortic valve.

A gross photo of the aortic valve shows stenosis with cuspal calcifications (arrows).

e. Marked sclerosis of a mitral valve.

The ring of posterior leaflet contains many calcifications (arrow).

だけでなく弁膜の fibrosa に石灰沈着をきたしている 例（Fig. 7e）があったのに対し，MVでは, 弁輪部 線維輪に強い石灰沈着をみる例 (Fig. 7f ) はあった が , 弁膜への石灰沈着が目立つ例はなかった .

\section{3. 非コラーゲン性骨基質蛋白質 (ON , OPN , OC)} の発現

(1) 大動脈・冠動脈での発現

石灰沈着部，粥腫部と谷の周囲間質，および macrophage 集簇部 (Fig. 8a にCA の石灰沈着部を示す)
でON，OPNの強い発現がみられた (Fig.8b，c) . OC は弹腫部と macrophage 集簇部での発現はみられ たが, 石灰沈着が主体となった部での強い発現は認め なかった (Fig.8d).

(2) 弁膜での発現

微小な石灰沈着部, 硝子樣変性部, および macrophage 集簇部 (Fig. 9a に A V の石灰沈着部を示す) で, ON , OPN，OC の強い発現を認めた(Fig. 9b，c， d).特に, 線維化の強い部や泡沫細胞集簇部で, OC の発現が動脈に比べて強い傾向がみられた . 


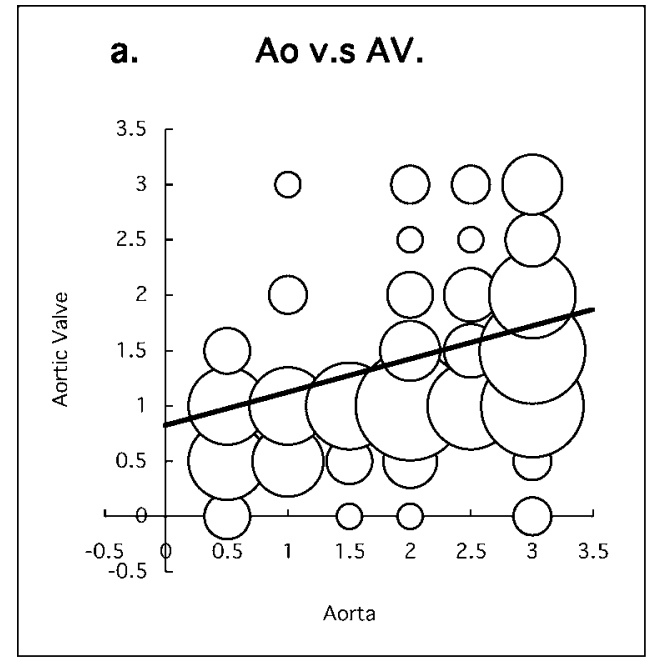

$A V=0.57+0.34$ * Ao $R^{2}=0.19$ $r=0.43 \quad(p<0.01)$

c. AV v.s MV.

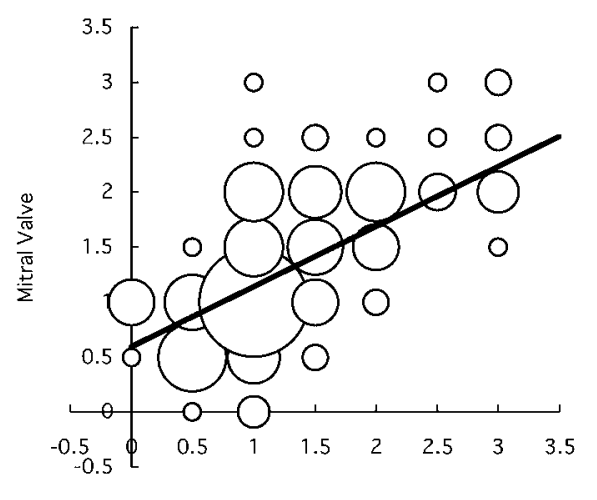

Aortic Valve

$A V=0.33+0.71 * M V R^{2}=0.42$ $r=0.65 \quad(p<0.01)$

e. CA v.s MV.

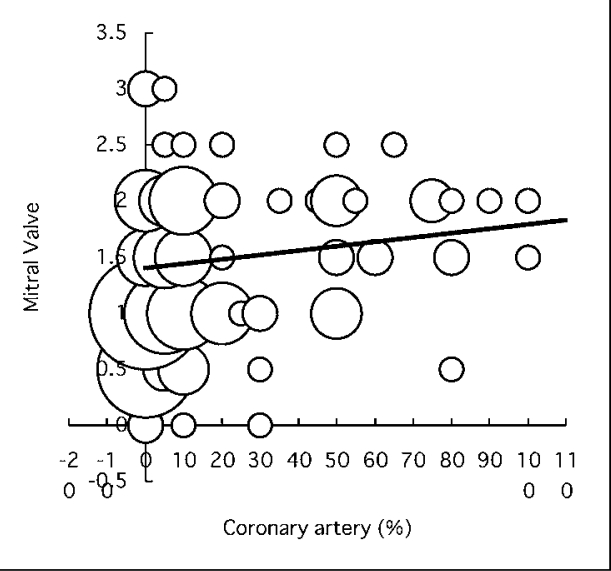

$M V=1.17+0.01 * C A R^{2}=0.08$ $r=0.35 \quad(p<0.01)$ b. Ao v.s MV.

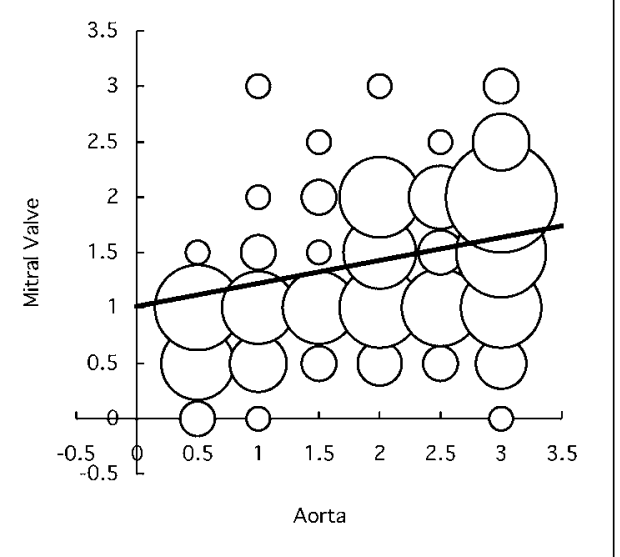

$M V=0.66+0.33 *$ Ao $R^{2}=0.21$ $r=0.46 \quad(p<0.01)$

d. CA v.s AV.

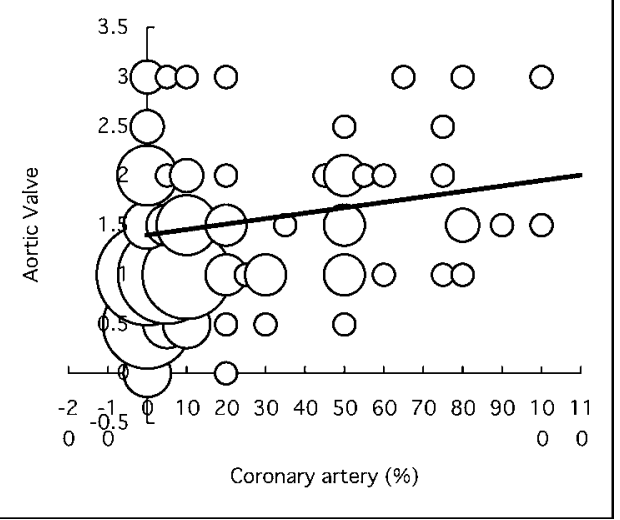

$A V=1.07+0.01 * C A R^{2}=0.12$

$r=0.35 \quad(p<0.01)$

Fig. 3 Correlations of scler otic changes between $A O$ and $A V, A O$ and $M V, A V$ and $M V$, $C A$ and $A V$, and $C A$ and $M V$, respectively .

There is a strong correlation between A o and $A V \quad(a, r=0.43 p<0.01)$, A o and $M V(b, r=0.46 p<0.01)$, and $A V$ and $M V$ (c, $r=0.65 p<0.01$ ), respectively.

However, the correlation between $C A$ and $A V(d)$, and $C A$ and $M V(e)$, respectively was weaker $(r=0.35 p<0.01)$.

$T$ he number indicates degree of sclerotic changes (see T able 1 ).

Each bubble size indicates the number of cases. 


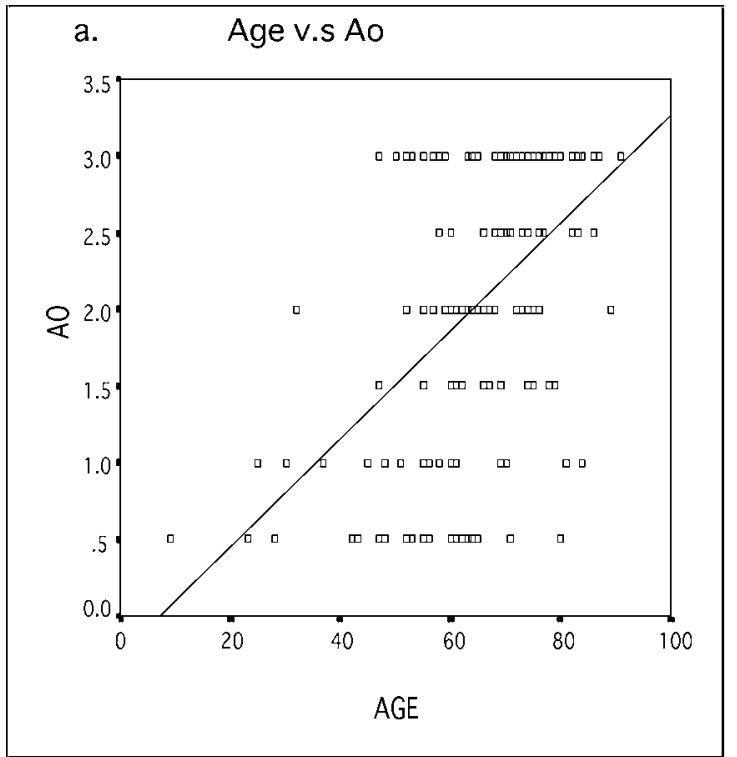

Ao $=0.04$ * AGE - 0.26 R $R^{2}=0.27$ $r=0.52 \quad(p<0.01)$

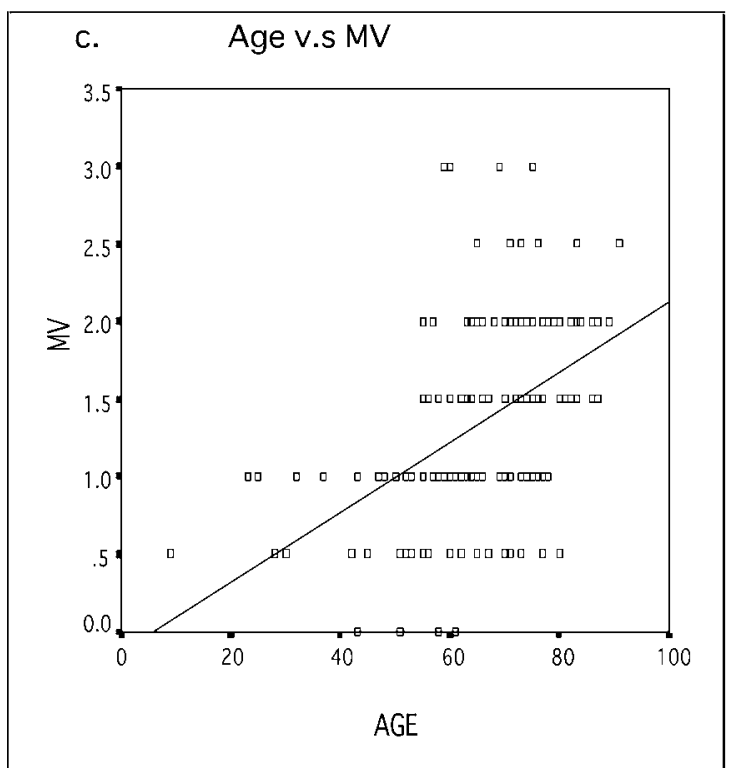

$M V=0.02 * A G E-0.14 \quad R^{2}=0.21$ $r=0.46 \quad(p<0.01)$

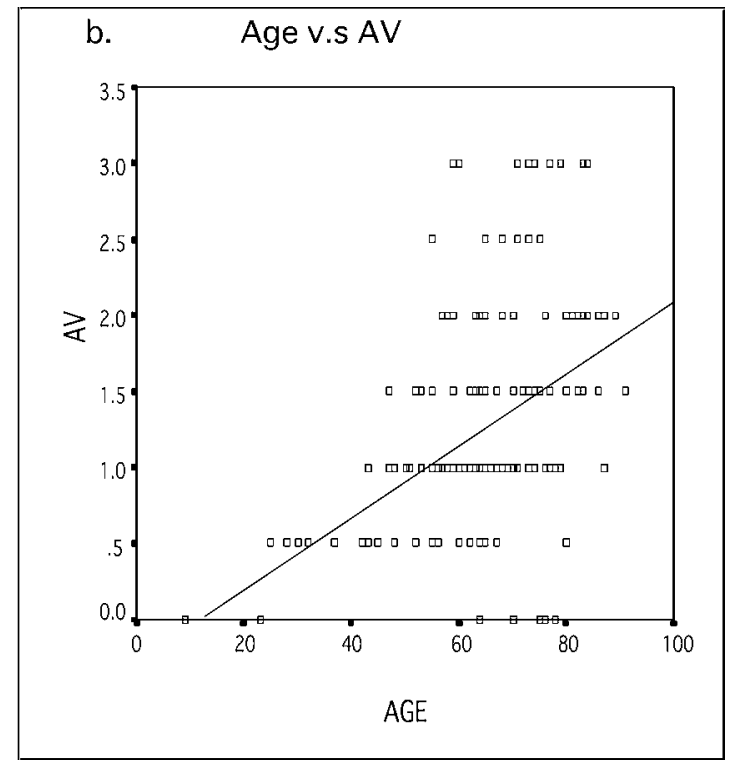

$A V=0.02 * A G E-0.27 \quad R^{2}=0.20$ $r=0.44 \quad(p<0.01)$

d.

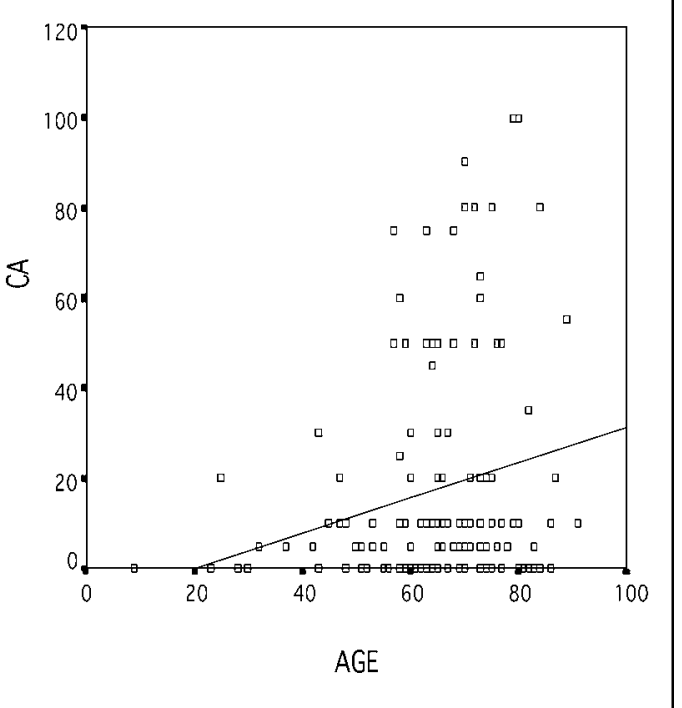

$\mathrm{CA}=0.32$ * AGE - 7.16 $\quad \mathrm{R}^{2}=0.04$

$r=0.22 \quad(p<0.01)$

Fig. 4 Correlations between patients' age and the degree of sclerotic changes.

Scler otic change of $A \circ \quad(a, r=0.52 p<0.01), A \vee \quad(b, r=0.44 p<0.01)$ and $M V \quad(c, r=0.46 p<0.01)$ strongly correlate with patinets' age, respectively.

T here is a weak correlation between A ge and CA $(d, r=0.22 p<0.01)$.

\section{考 察}

1. 動脈硬化と心臓弁膜硬化の関連性

動脈硬化と心臟弁膜の硬化について，関連性を指摘 する論文は多い .これは, 高齢者では $\mathrm{MV} \cdot \mathrm{AV} \cdot \mathrm{CA}$ の3点での石灰化が一般的に認められるこど, 大動
脈弁や僧帽弁に石灰沈着がみられる症例で大動脈粥腫 が有意に多く認められること年, 大動脈弁や僧帽弁の 硬化と大動脈粥状硬化に対する臨床的な risk factor

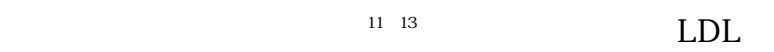
酸化 LDL など，血管の硬化巣と弁膜硬化部で認めら れる脂質に共通性があること年-16 などから論じられて いる．しかしこれらの検討は, 大動脈弁と大動脈間ま 


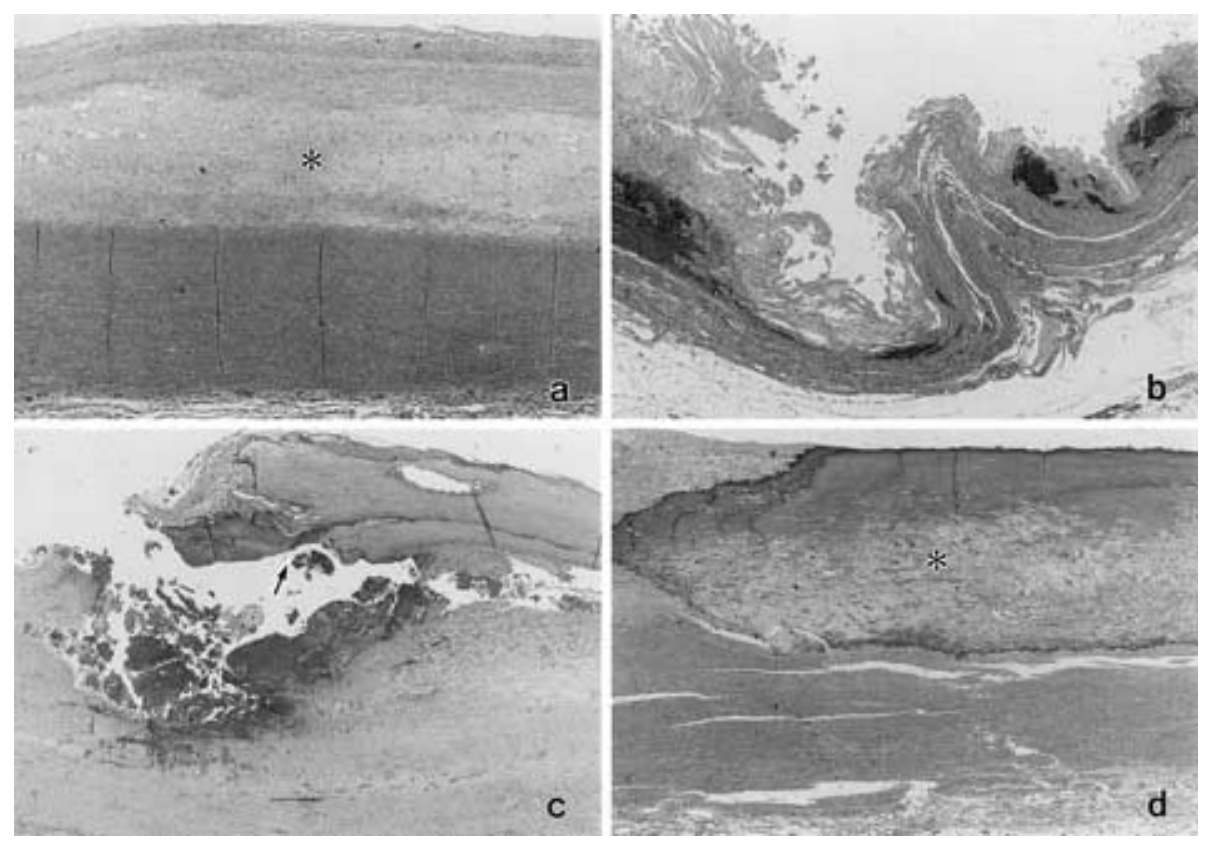

Fig. 5 Microscopic findings of aortic sclerosis. (U pper side is the aortic lumen in all figures.) a. Fibrous plaque sometimes contains atheromatous lesions (asterisk) at the center of thickened intima. (H-E stain, a 66-y ear-old woman)

b. Complicated sclerotic lesions have ulceration of atheromas with focal calcific deposits. (EMG stain, a 57-y ear-old man )

c. A severe calcification (arrow) is observed in the atheromatous lesion. (H-E stain, a 85-year-old woman )

d. A $n$ extensive calcification (asterisk) is associated with thickening of intima. (H-E stain, a 69-yearold woman)

たは僧帽弁と大動脈間での関連性に限って行われてお り，共通する対象において Ao，CA，AV，MVの全 てを一度に検討した報告はほとんどない，また，硬化 所見の関連性についての検討は超音波検査所見を主体 とした臨床検査上のデータに基づいており，臨床的に はとらえきれない軽度の硬化性病変を含めた病理学的 所見に基づく検討はなされていない．

今回の剖検例を用いた病理学的検討では，肉眼的な 硬化度において ,A o-A V ,A o-MV ,A V-MV ,CA-A V ， CA -MV の各組織間に有意な相関を認め, 他の報告と 同樣に動脈硬化と心臓弁膜硬化の進行には関連性力認 められた .これら各組識の硬化性変化は年齢とも相関 しており，血管および心藏弁膜の硬化は加齢に伴い進 行することが確認された .

一方，個々の症例をみると，動脈硬化が高度である にもかかわらず心臓弁膜硬化は比較的軽い例や，一つ の組織の硬化が突出して高度である例がみられるな ど，組織間の硬化度は必ずしも一致しなかった .この ような差を生じる主な原因として，動脈と弁膜におけ る血行力学的ストレスの違い, および基本的な組織構 造の違いが考えられる。

\section{2. 動脈硬化と弁膜硬化の相違}

(1) 血行力学的ストレスの違い

血流, 特にずり応力と動脈硬化の関連性について は, 低ずり応力部で血中の単球やリンパ球が内皮に接 着しやすいこと ${ }^{17}$, 乱流部では内皮細胞増殖が刺激さ れ，細胞の turn over 時に発生する間隙から血中 LDL (low density lipoprotein) が内皮下へ侵入し蓄積さ れていくこと ${ }^{18}$,ずり応力の影響を受けて内皮に発現 する LOX-1 (lectin-like oxidized LDL receptor-1) が 粥状硬化病変部の内皮細胞で増加発現されているこ と ${ }^{19}$ など , ずり応力の低い部分で脂質の滲み込みや動 脈硬化が進行しやすいことが多くの分子医学的研究で 明らかにされている .

一方心藏弁膜へのストレスのかかり方は，動脈とは 異なる．すなわち，血管内では原則として血流の方向 は一定であるのに対し，弁膜では，開放時と閉鎖時に 弁膜自体も動くことに加えて，弁膜にかかる圧も大き く变化するために, 多樣なストレスが生じていると考 えられる.ずり応力についても，心臓弁膜では開放時 に血液流入面が血管壁と同樣のストレスを受けるだけ でなく，裏側の閉鎖面でも血流にともなう乱流が生ず 


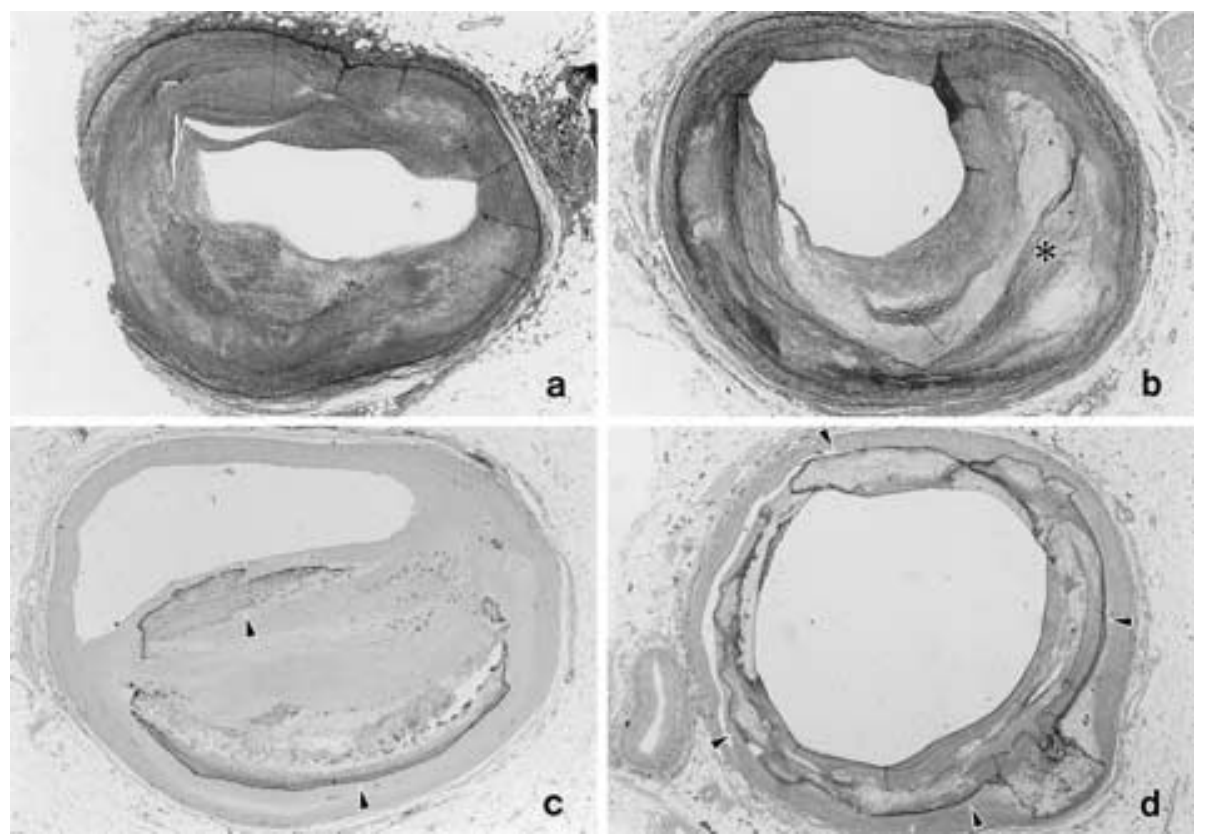

Fig. 6 Microscopic findings of atherosclerosis in a coronary artery.

a. A photomicrograph of cross-section shows narrowing lumens with fibrous thickening of intima. (EMG stain, a 59-year-old man)

b. A rterial lumen show narrowing with atheroma (asterisk). (EMG stain, a 72-year-old man)

c. A calcific deposit (arrowheads) is observed in the atheromatous lesion. (H-E stain, a 57-year-old man)

d. T he coronary artery shows dilatation with a circumfer ential calcification (arrow heads) of the wall.

(H-E stain, a 69-y ear-old woman)

る可能性がある . 閉鎤時では , 流入面には弁閉鎖運動 に伴う乱流が，閉鎖面には閉鎖するための血流がゔつ かることによる乱流が発生すると考えられる．したが ってずり応力が深く関連するのであれば，弁膜の両面 に硬化性変化が見られてもよいと思われるが，今回の 検討で弁の硬化性変化は閉鎖面 (fibrosa側) のみに 限局していた .

ウサギに高コレステロール食を与えた動物実験で， 大動脈弁では壁在ストレスが最大となる大動脈面での み動脈硬化性病変が発生することから,ずり応力では なく壁在ストレスが弁硬化の進展の主因であるとする 報告がある ${ }^{20}$. しかし弁膜硬化に影響するストレスが 主に組織にかかる圧力であるならば，大動脈圧を受け るAVよりも左室圧を受ける MV で高度な硬化をき たしているはずである．今回の検討で， A V では弁膜 に石灰化をともなう硬化が及んでいるのに対し，MV では石灰沈着をともなう強い硬化は弁輪を主体として いた．したがって，心藏弁膜の硬化に関連するストレ スは単純ではなく，組織に対する圧が主体をなすが， ずり応力や弁膜自体の運動も複雑に絡み合っている可 能性があると考えられた .
（2）組織構造の違い

血管では中膜にある平滑筋細胞が，動脈硬化に重要 な役割を果たしていることが多くの研究で明らかにさ れている ${ }^{21-23}$.一方，心藏弁膜には，血管中膜にみら れるような平滑筋細胞の層は存在していない . 今回の 検討で, 弁膜の硬化性変化は弁輪および fibrosaの膠 原線維の加齡性硝子樣変性が主体であり，石灰化をき たしても硬化はfibrosaを越えては広がらないことが あきらかとなった . macrophage の局所的な存在がみ られたが表在性であり，fibrosa 内部への浸潤はみら れず，動脈にみられるような粥腫形成に至った例はな かった、したがって, 基本的な組織構造の違いと, 硬 化進展に関与する平滑筋細胞や macr ophage の存在お よび光の役割の違いが, 動脈硬化と弁膜硬化の相違に 深く関連していると考えられた .

高度な硬化変性で問題となる臨床的な病変は, 動脈 と心藏弁膜では基本的に異なる.動脈では，血栓の形 成, 閉塞, 大動脈瘤形成と谷の破綻など, 主に弹腫形 成に起因する障害が問題となるのに対し，心臓弁膜で 問題となるのは石灰沈着による弁機能障害である . こ の石灰沈着病変の組織像について, 動脈と心藏弁膜で 比較すると，動脈では，糊腫主体の領域に石灰沈着を 


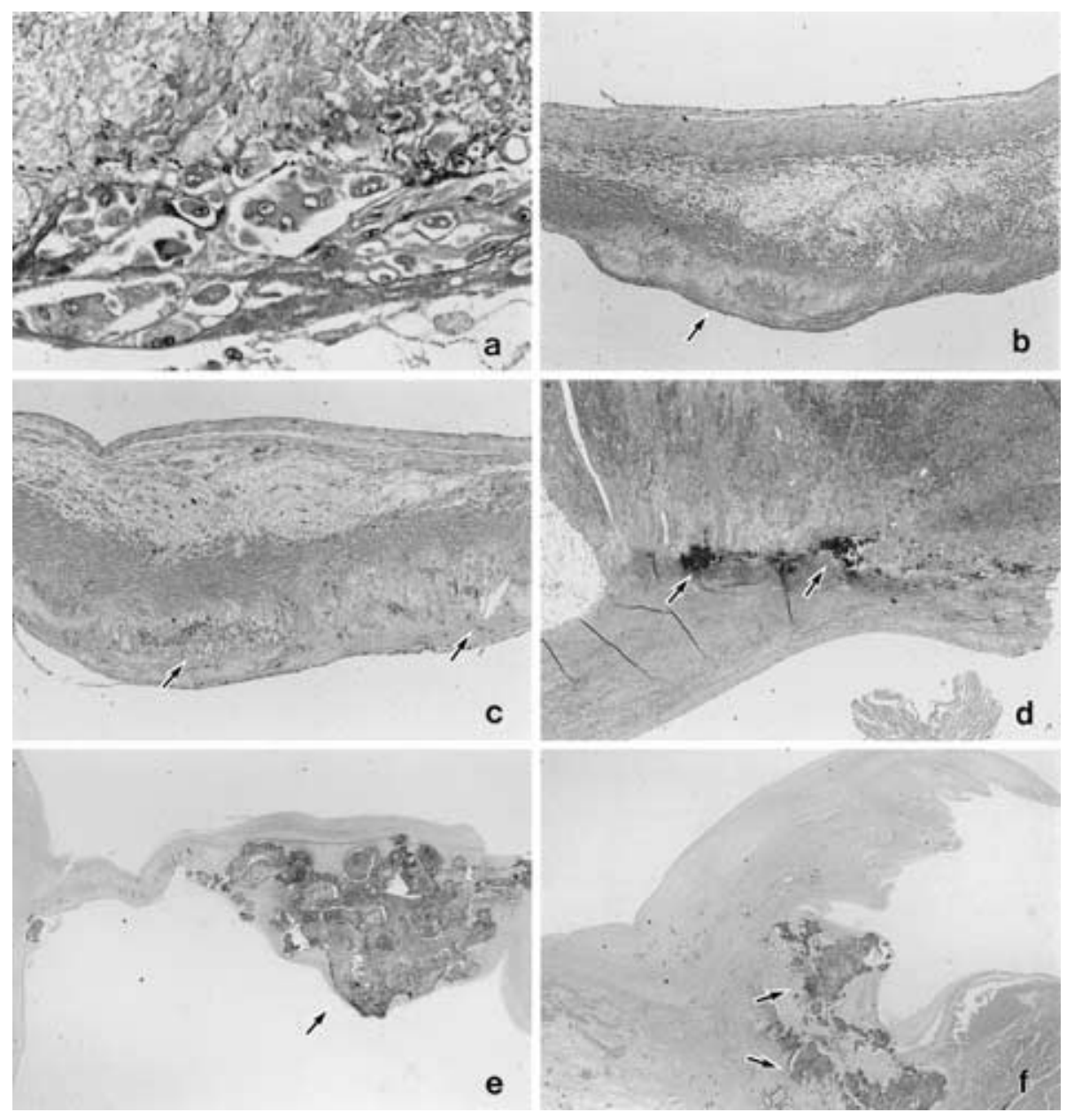

Fig. 7 Microscopic findings of valvular sclerosis. (Upper side is an inflow surface of the valve in all figures.)

a. Foamy macrophages accumulate at the ventricular surface of the mitral valve, but not infiltrate into the fibrosa. (EMG stain, a 47-year-old man)

b. Bundle of collagen fibers in the fibrosa of aortic valve show hyalinous change (arrow). (H-E stain, a 50-year-old woman)

c. The fibrosa with hyalinous change of the mitral valve contains scattered cholesterin clefts (arrows), but not form an atheromatous lesion. (H-E stain, a 65-year-old man)

d. Focal small calcified deposits (arrows) are observed in the fibrous ring of the aortic valve. (H-E stain, a 89-year-old man)

e. T he calcification extends into the thickened fibrosa of aortic cusp (arrow). (H-E stain, a 73-year-old man)

f. The calcification localizes at the fibrous ring (arrows) of the mitral valve, and does not extend into the leaflets. (H-E stain, a 69-year-old woman)

きたしているものと，線維性肥厚部に石灰が沈着して いるものがみられたのに対し，心臓弁膜の石灰沈着 は, fibrosaの硝子樣変性部を中心に進展していた . すなわち組織上は, 動脈の線維性肥厚部への石灰沈着 か心蔵弁膜の石灰沈着像と類似しており，このような 線維化巣への石灰沈着と，粘腫を主体とする病巣では 硬化の機序が異なる可能性が示唆された .

組織の石灰化については，ON が石灰化開始に関与 していること，OPN は石灰沈着とほぼ同時に認めら
れ，石灰化の進行とともに増加すること，OC は高度 に石灰化した部位に限局し，石灰化初期までは認めら れないことなどが指摘されている゙2. 特に粥状動脈硬 化の石灰化層を取り巻く macrophageには, OPNの 多量な発現力゙認められている でも，石灰化と macrophage 集簇の程度および OPN 発現の程度に有意な相関を認めたという報告があ $3^{26}$. 今回の検討では, OC の発現が動脈より心臓弁 膜で強い傾向がみられたが，ON および OPN の発現 


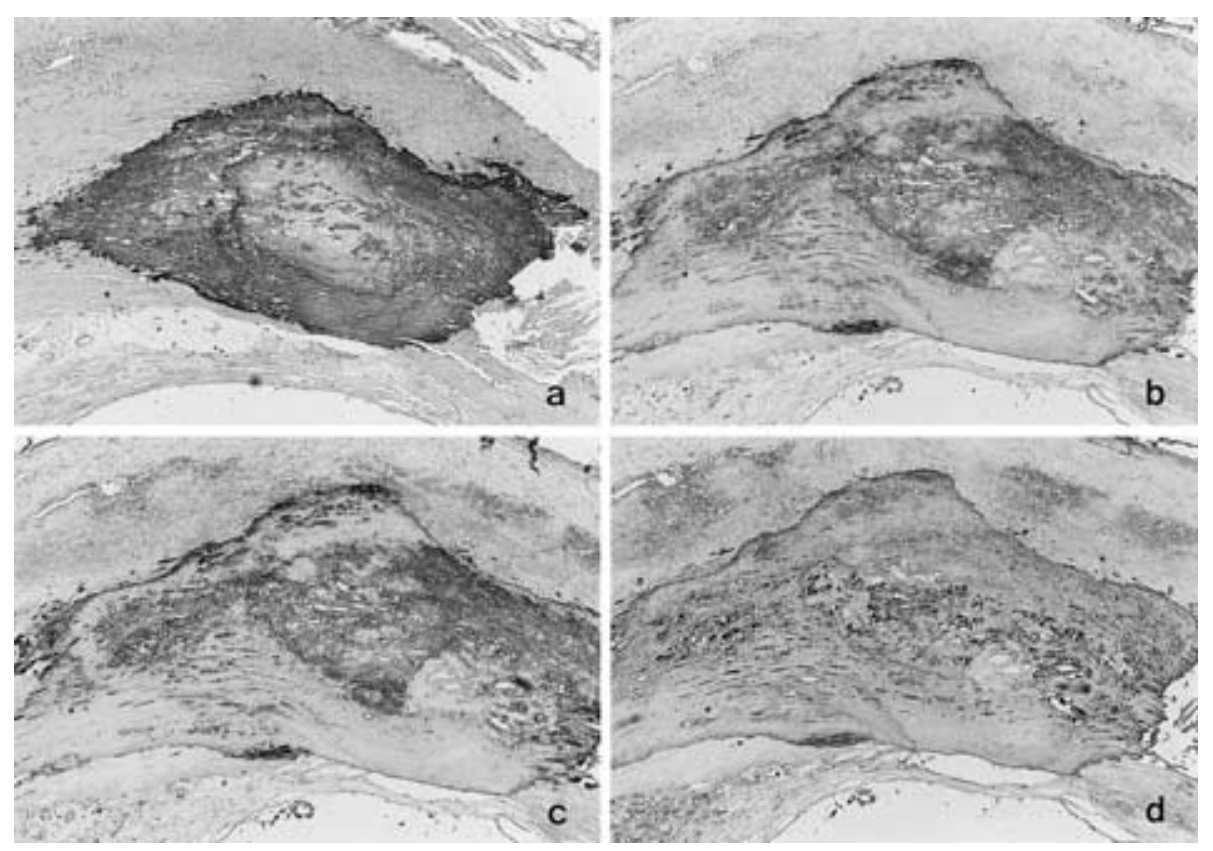

Fig. 8 Immunohistochemistry for bone related proteins in serial sections of a coronary artery (a 76-y ear-old woman ).

The calcification of the thickened arterial wall (a: H-E stain) show s positive reaction for osteonectin (b) and osteopontin (c). Reactivity for osteocalcin (d) is relatively weaker.
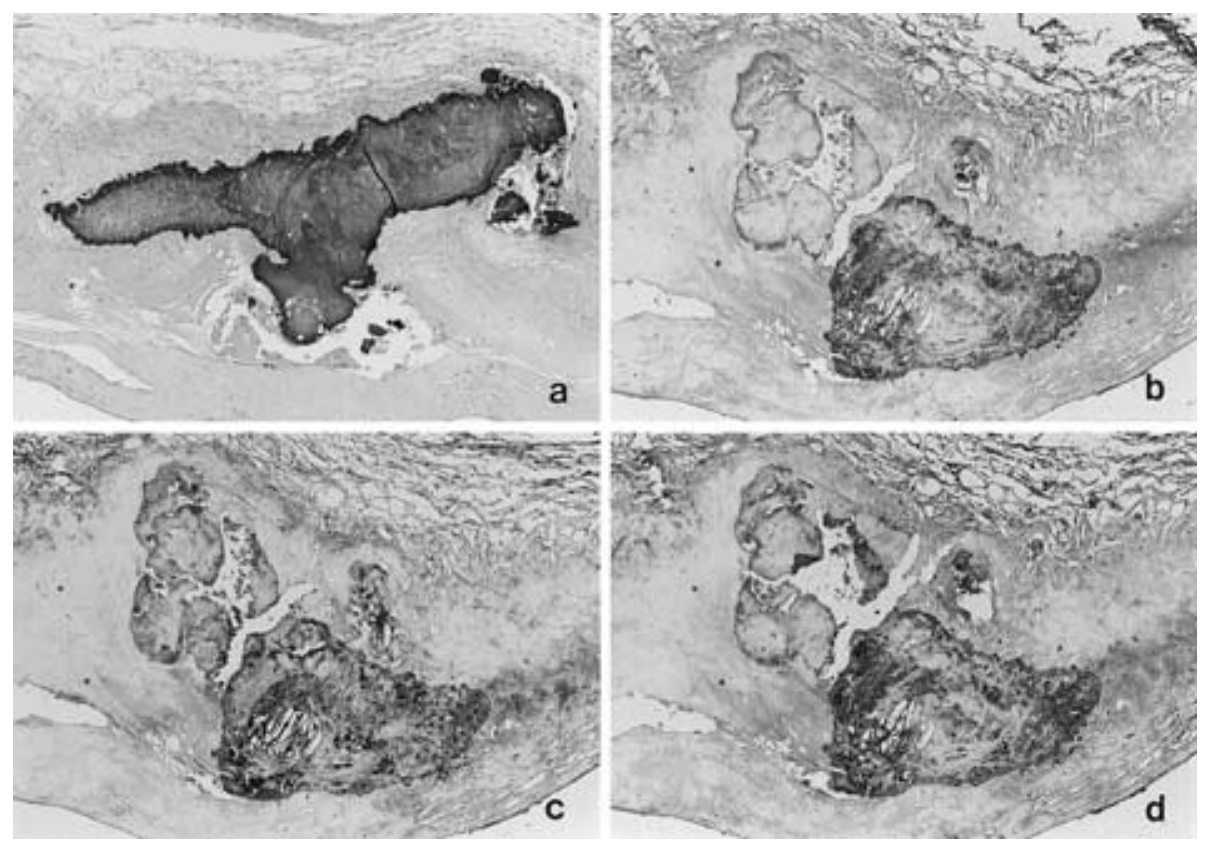

Fig.9 Immunohistochemistry for bone related proteins of the aortic valve (a 78-year-old man) . The calcification of the fibrosa ( $\mathrm{a}$ : $\mathrm{H}-\mathrm{E}$ stain) show s positive reaction for osteonectin (b), osteopontin (c) and osteocalcin (d). Note that the reactivity for osteocalcin is stronger than that of the artery (compared with $8 d$ ).

は動脈と心臓弁膜の間で明らかな差はみられなかっ た .また動脈硬化病巣の中で, 弁膜の石灰沈着と類似 した線維性肥厚部への石灰沈着領域と，䉼状硬化部へ の石灰沈着領域におけるこれらの蛋白の発現にも，明
らかな差は見出せなかった ．しかし今回の検討で明ら かなように , 弁膜への石灰沈着は加齢にともなう膠原 線維の変性を基盤としており，加齢性弁硬化症の予防 のためには弁膜組織への石灰沈着機序を中心にさらに 
検討を要すると考えられた 。

\section{結 語}

動脈硬化と心臓弁膜硬化の関連性について, 剖検例 を用いて検討した 。

1. 統計学的には, 動脈, 冠動脈, 大動脈弁, 僧帽 弁の硬化は加齢に伴い進行しており，組織間の硬化度 に関連性が認められた．しかし個々の例でみると，各 組識の硬化度は必ずしも一致していなかった 。

2. 組織上, 弁膜では動脈硬化病巣のような粥腫形 成は見られず，硬化は弁輪部線維輪および fibrosaの 膠原線維の硝子樣变性から石灰沈着に至る变化が主体 であった .

3. 非コラーゲン性骨基質蛋白質の中で, osteocalcin の発現が，血管の石灰沈着部に比べて弁膜硬化部で強 くみられる傾向があり，硬化像の違いに関連している 可能性があった .

4. 動脈と心藏弁膜では基本構造や組織にかかるス トレスに違いがあることから，乥の硬化機序も異なる 可能性が高く, 近年増加している弁膜の硬化性機能障 害を予防するためにさらなる検討を要すると考えられた ．

本研究の病理組織標本作製には, 日本医科大学病理学 第1教室の若松恭子氏に多大なるご協力を頂いた .ここ に感謝の意を表したい . 本論文の要旨の一部は, 第 70 回 日本医科大学医学会総会 (2002年 9 月, 東京)，および第 92 回日本病理学会総会 (2003 年 4 月, 福岡) にて発表した。

\section{文 献}

1. A ngelini A , Basso C, Grassi G, Casar otto D, T jiene G: Surgical pathology of valve disease in the elderly. A ging (Milano) 1994; 6:225-237.

2. Ornish D, Brown SE, Scherwitz LW, Billings JH, Armstrong WT, Ports TA, McLanahan SM, Kirkeeide RL, Brand RJ, Gould KL:Can lifestyle changes reverse coronary heart disease? The Lifesty le Heart T rial. Lancet 1990; 336: 129-133.

3 . 寺元民夫 : 脂質低下剂の現況と展望 . 医学のあゆみ 2000; 193: 433-438.

4. Frei B:Cardiovascular disease and nutrient antioxidants: Role of low density lipoprotein oxidation. Crit Rev Food Sci Nutr 1995; 35: 83-98.

5. Stary HC, Blankenhorn DH, Chadler A B, Glagov S, Insull $W$, Richardson $M$, Rosenfeld ME, Schaffer $S A$, Schwartz CJ, Wagner WD, Wissler RW: A definition of the intima of human arteries and of its atherosclerosis-prone regions. Circulation 1992; 85: 391-402.

6. Stary HC, Chadler A B, Glagov S, Guyton JR, Insull W, Rosenfeld ME, Schaffer SA, Schaffer SA, Wagner
WD, Wissler RW:A definition of initial, fatty streak, and intermediate lesions of athorosclerosis. Circulation 1994; 89: 2462-2478.

7. Stary HC, Chadler AB, Dinsmore RE, Fuster V, Glagov S, Insull W, Rosenfeld ME, Schwartz CJ, Wagner WD, Wissler RW:A definition of advenced types of atherosclerotic lesions and a histological classification of atherosclerosis. Circulation 1995; 92: 1355-1374.

8. Roberts W C: Morphologic features of the normal and abnormal mitral valve. A m J Cardiol 1983; 51:10051028.

9. A dler $Y$, V aturi M, W iser I, Shapira $Y$, Hertz I, W eisenberg $D$, Sela N, Battler A, Sagie A : Nonobstructive aortic valve calcium as a window to atherosclerosis of the aorta. A m J Cardiol 2000; 86: 68-71.

10. A dler Y, Fink N, Spector D, W iser I, Sagie A : Mitral annulus calcification: $A$ window to diffuse atherosclerosis of the vascular system. A therosclerosis 2001; 155: 1-8.

11. Stew art F, Siscovick D, Lind B, Gardin J, Gottdiener J, Smith V, Kitzman D, Otto C: Clinical factors associated with calcific aortic valve disease: Cardiovascular Health Study. J A m Coll Cardiol 1997; 29: 630-634.

12. Boon A, Cheriex E, Lodder J, Kessels F:Cardiac valve calcification:Characteristics of patients with calcification of the mitral annulus or aortic valve. Heart 1997; 78: 472-474.

13. 鈴木 伸, 佐藤孝一, 谷口正仁, 宮川浩一, 小嶋正義, 土肥靖明, 上田龍三: 老年者大動脈弁硬化におけるリ ポプロテイン (a) の意義 . 日医老誌 1998; 35: 444-450.

14. Olsson M, Thyberg J, Nilsson J:Presence of oxidized low density lipoprotein in nonrheumatic stenotic aortic valves. A rterioscler Thromb Vasc Bio 1999; 19: 1218-1222.

15. Mehrabi $M$, Sinzinger $H$, Ekmekcioglu $C, T$ amaddon F, Plesch K, Glogar H, Maurer G, Stefenelli T, Martha Lang I:A ccumlation of oxidized LDL in human semilunar valves correlates with coronary atheroscler osis. Cardiovasc Res 2000; 45: 874-882.

16. Obrein K, Reichenbach D, Marcovina S, Kuusisto J, A Ipers C, Otto C:A polipoprotein B,(a), and E accumulate in the morphologically early lesion of degene rative" valvular aortic stenosis. A rterioscler Thromb V asc Bio 1996; 16: 523-532.

17. A ndo J, T suboi H, Korenaga R, T akada Y, T oy amaSorimachi N, Miyasaka M, Kamiya A: Shear stress inhibits adhesion of cultured mouse endothelial cells to lymphocy tes by downregulating VCA M-1 expression. A m J Physiol 1994; 267:679-687.

18. Weinbaum S, T zeghai G, Ganatos P, Pfeffer R, Chien $\mathrm{S}$ : Effect of cell turnover and leaky junctions on arterial macromolecular transport. A m J Physiol 1985; 248: 945-960.

19. Murase T, Kume N, Korenaga R, A ndo J, Saw amura $T$, Masaki T, Kita T : Fluid shear stress transcriptionally induces lectin-like oxidized LDL receptor-1 in vascular endothelial cells. Circ Res 1998; 83: 328-333.

20. Mano J, Thubrikar J, Deck D, A oud J, Chen JM:Intramural stress as a causative factor in atherosclerotic lesions of the aortic valve. A therosclerosis 1985; 
55: 299-311.

21 . 由谷親夫, 藤田寛敬, 高市成子, 山本 章 : 動脈硬化 の発生・進展における血管平滑筋細胞の役割 : 動脈硬 化発生・進展の解明. 住吉昭信編 . 1991; pp 59-67, 共立出版, 東京。

22. 森聖二郎, 齋藤 康 : 血管平滑筋細胞の遊走・増殖の メカニズムとプラークの安定化 . 動脈硬化 2000; 27: 117-122.

23. 北 徹 : 動脈硬化の分子機構 .Mebio 1999;16:17-24.

24. 廣田誠一, 中瀬尚長, 嶽村貞治, 野村慎太郎, 高岡邦 夫 : 遺伝子発現樣式からみた生理的石灰化と非生理的
石灰化の関連性 . 細胞工学 1994; 13: 28-37.

25. 野村慎太郎, 佐藤宗彦, 寺井邦博, 川畑浩久, 杉本瑞 生 : オステオポンチンからうかがう骨組織. 細胞工学 1998; 17: 349-357.

26. Obrein K, Kuusisto J, Reichenbach D, Ferguson M, Giachelli C, Alpers C, Otto C:Osteopontin is expressed in human aortic valvular lesions. Circulation 1995; 92: 2163-2168.

(受付：2003年 2 月17日) (受理 : 2003年 7 月 2 日) 